\title{
Protecting the Endangered Biodiversity in The Gilgel-Gibe Rivers Basins Ethiopia: Need for Multi-Disciplinary Approaches and Enlightenments.
}

\author{
Mailafiya Aruwa Filaba*
}

\begin{abstract}
The major objectives of the survey were: To ascertain the degree of endangering the biodiversity in the basins; to inform the professionals and farmers how their activities contribute to environmental degradation; to encourage the communities to initiate mitigating measures to arrest environmental degradation; to influence the farmers, fuel-wood dealers and brick industrialists to be aware of environmental protection laws; to fight desertification; to be conscious of environmental degradation; and to conserve the ecosystem in the basin. Scope and Population included the Forest workers in the various Wareda sharing the basin, farmers on the banks of the river, and the patrons of the flora and fauna there for commercial purposes - fuel and Lumber Dealers using Trucks; Block Industries; Local fishermen and hunter - in the Gilgel and Gibe basins. Interviews and focused group discussions [the number of respondents per group ranged between 8 and 15 depending on the mobilization of the community leaders] were conducted in 20 settlements $20 \mathrm{~km}$ on the banks up the Gilgel river and 20 settlements from Gibe Dam up river were covered. The findings reveal that the basin is a major food basket in Ethiopia, and arable and animal farming have been going on there since time immemorial with the gradual consequence of environmental degradation in many forms. The project concluded with submission of suggestions like the need for government to embark on awareness campaign to enlighten farmers and professionals on the need to conserve natural resources, obey the environmental protection laws, and need for grants for indepth researches on the impact of human activities on the biodiversity of basins. The flora and fauna in the basins are already endangered. Perhaps, tree planting and other methods that can forestall the imminent erosion and desert incursions are a desideratum.
\end{abstract}

\section{Introduction} The action research was aimed at
examining the nature and extent of endangering the biodiversity in the basins, and setting up mitigating measures through inter-face consultation/enlightenment of the targeted population of study - the farmers and professionals (fuel wood and lumber dealers and brick industries) on the need to protect the flora and fauna in the basin. Many studies have established the fact that apart from gully and wind erosions, African soils are being constantly threatened by some traditional farming methods that increase soil erosion and desertification, the process in which soil dries out until almost no vegetation grows on it. While some of the measures to check land depletion like restricting herding, bushburning, hunting and so on, have been resented by farmers (Stock, 2006).
This study examines the problem of endangered biodiversity in the basin. Both the flora and fauna are endangered around GilgeGibe wanz (river) basins as a result of increased human activities, urbanization and construction of the dam (hayk) ; and there is no regard for the conservation of the ecology or observation of the existing forest and games reserve laws. To get the study focused these were the major research questions posed: How was the ecology of the area a millennium ago? How had it changed and what factors were responsible? How was the biodiversity of the area at the eve of the creation of the dam? How is the biodiversity now? What are the various zoological, archaeological, paleontological, environmentalist, hydrological, bio-chemistry and even farmers' perspectives of the changing biodiversity of the area? What are the various human activities that correlate to the environmental

*Faculty of Education, Jimma University, Jimma, Ethiopia mfilaba@yahoo.co.uk 
degradation in the basins? What are the

environmental degradation? How can the problems be approached and what mitigating measures can be put in place to safeguard the flora and fauna and as well curb environmental pollution? To systematically obtain the records of the above professional groups is an expensive and protracted endeavour. However, we can put in record what can be got and seen now, which data may be used for subsequent comparative study of the changing biodiversity of the area.

Two hypotheses were drawn: "Enlightening people on the effects of rapid environmental degradation can influence the desire to conserve the environment;" and "Environmental degradation is potent conflictinfluencing factor and adversely affects the economy of the region." The first hypothesis was tested. Group leaders were visited towards the end of the project for feedback. They were optimistic that with re-enforcement using the media and notices from the Waredas, people are becoming more conscious of environmental degradation. On the second hypothesis, they alluded on the fact that the gradual depletion since time immemorial forced some groups to move to more-fertile areas and met with conflicts some of which are still fresh in their memories.

Thus, the significance of this project is to influence the desire for conservation of the fauna in the basins and as well enable the soils to retain the fertility for continuous mixedfarming cultural pursuit, which has been the main occupation of the people in the area. The conservation of the environment will have the additional impact on reducing environmental pollution. Indeed, the rivers and ponds in the basins are the main sources of drinking water. In addition to the major objectives mentioned in the abstract, the specific objectives of the project were to: teach farmers how to trim

The Issues for Focused Group Discussions (FGDs) and In Depth Interviews (IDIs) Guides are: How old are the settlements and what they farm; Instruments of farming; Why they clear all trees; Whether they attach any effects to total clearing of wood; Any community wood protection taboos/decrees; Various domestic uses of wood in the community; Identify areas/farms in the associated effects of the rapid

trees and still get maximum yields without necessarily falling all the trees; educate fuelwood (ancat) and Wood/Lumber dealers to respect forest reserve laws; educate Brick Industries on how to protect aquatic life; educate local fishermen on the effects of the use of poisons in fishing; to liaise with Forest Workers and the Wareda sharing the basin for identifying Government Forest and Games Reserves in the area.

\section{Methodology}

The study area covered 29 settlements along the road and around Gibe Dam (hayk) and Gilge river (wanz) all within the GilgelGibe Basin and the fieldwork was carried out between May to December 2007. Direct observation technique, In-depth Interviews (IdI) and Focus Group Discussions (FGD) were employed for data collection.

20 Focus Group Discussions (FGDs) were conducted among selected farmers of ages 30 to 60 years, with an average of 9 participants in each FGD group. In addition 28 in-depth interviews were conducted for community leaders, wood dealers and brick makers (i.e 20 community leaders, 6 wood dealers and 2 brick industrialists in Jimma town). The settlements involved in the study include; Jimma, Daraba, Gilbe, Asendabo, Nada, Gandi, Fola, Deneba, Gangeleta, Karsa, Afata, Denaba, Simini, Dereta, Kofta, Kubeta, Gobe, Kumbi and Andode; others are, Nacha, Debo, Rogoda, Ilala, Nano, Diko, Bacamoti, Agelo, Suntu and Bage. Other scheduled activities covered by the research were: Visits to farms and demonstrating trimming of trees; Visits to Forest and Games Reserves; Collection of names of endangered flora and fauna species of the area; and Production of maps showing Forest Reserves and endangered streams.

community suffering from gully erosion; Mention the local methods of checking erosion; What techniques are used in fishing here; Whether some people use poison in fishing here; The perceived effects of poison when used in fishing; Methods of hunting here; Name the fauna that are being endangered here; Whether there are traditional hunting laws intended to protect some species; 
Illegal lumbering in the area and how frequent, and estimates of number of trips/week; Types of natural plants are endangered; Any other individual and commercial activities going on in the basins that have some dangers to the water, soil, animals/birds, and human health; Response of the community to the activities affecting the fauna and human beings; Whether aware of environmental protection laws and forest preservation laws, whether the laws are respected or not; What the community does to enforce the environmental protection laws; Identify the Forest and Games Reserves in the environs and whether they protected or not. Importance of tree trimming protection of Forest and Games Reserves to be stressed by the conductor of the FGDs

\section{Results and Discussions}

\section{Description of the Study Area, its Physical features and Settlement Pattern}

Gilge basin covers all the areas it takes its headwaters. To the north it takes its waters from the ravines and streams starting from Wangele shet (hills) and runs down southward joining Gibe near Abelti. Other streams start near Jima and run northward joining Gilge near Agelo. Its eastern streams start from Fino, Chando and Kono area joining Gilge near Abeti. The streams and valleys which waters drain down to Gibe Dam start some $50 \mathrm{~km}$ west of Jimma, from Saddaro, Sembo and Kemo hills which have small streams as water head; and from Kemo, Dedo, Mal Gudo and Komboloti valleys and streams in the south of Jima, and run north-east wards parallel with Omo basin to the east and empty into Omo river. Nebo river and other streams on the northern direction join with those from south of Jima some $20 \mathrm{~km}$ east of Jima near Daraba and pass through Gibe emptying into the Dam. From the dam the river runs parallel northeastwards with Omo basin and with other streams join Gilge that empties into Omo river near Abeti Jima-Addis bridge some 10kms east of Welkite. The streams from around Jima in the West of Gibe and from Nebo to the north are critical to the Gibe basin and the Dam the major source of pipe-bone water and fish in the region and beyond. Activities in this region have direct impact on the quality and danger of the Dam.
The basins fall in the Rift Valley and thus characterised by deep and dry ravines which are the water-heads of the rivers. The Gibe river has many marshy/paddy zones as its water heads. The rivers meander through the hills and gorges, with patches of bushes/forests on the foothills that are rocky and cannot be farmed. These are the bushes some fauna are found. On the slow slops and plains are farms, all divided in squares for farming mainly fonio (teff), barley (gabs), wheat, rice, soup ingredients, guinea-corn and maize. Close to the river bed and in the paddy zones particularly around the settlements are small plantations of banana, coffee arabica, avocado, gista, phoenix reclinata, sugar-cane, Khat, coffee arabica, avocado, gista, phoenix reclinata, sugar-cane, hybrid trees - Christmas tree (Tsedi) and Barzau, and overgrowth of acacia and local trees.

The soil is generally black but mixed with pebbles and mountain rubbles. Thus pieces of stones characterise the uplands. The soil is sticky and tough that most of the harrowing is done by using cows. Diggers and hoes are used for tilting the soil. The top soil is generally fertile, and has been farmed since time immemorial. Much of the fallows are completely infertile and stony due to centuries of farming. Aerial view reveals the square farms in the basin and the rivers like decorated carpets with streams appearing like thin meanderous white strips, and the hills like big moulds and ridges, while grazing cattle could be sported like clusters of spread white seeds, and the huts like sprinkled grains.

The basins some 50 years ago had almost every type of African animal populations. Of course, the whole of East and Southern Africa still have in abundance the big game animals, herds of herbivores, and abundant bird species more than other regions of Africa. Big games like elephants, black and white rhinoceroses, African buffaloes, giraffes, and hippopotamuses are no more in the basins. Zebras, antelopes, elands, duikers, hartebeests, impalas, topis, oribis and kobs can be sported in the bush. The baboons, monkeys and rodents are still in large numbers. The predator carnivores particularly lions, leopards, cheetahs, and hyenas are in the forests and hills. The basin is also rich in birds, particularly hawks, eagles, falcons, vultures. 
Other identified birds are rollers, kingfishers, bee-eaters, larks, pipits flycatchers, bulbuls, babblers, warblers, swallows, crowned-crane, guinea fowl, ground hornbill, marabou stork, flamingos and queleas. There are also reptiles like crocodiles, lizards, monitors, chameleons and geckos. There are many types of snakes the commonest being vipers, cobras pythons and mambas (Stock 2006).

Settlement pattern is sparse. Some settlements look like temporary booths, but have been there for years as permanent residences. Except in Jimma and other market canters the whole population in the basins is agrarian engaged in mixed farming, which is complemented with fishing, trading and crafts production - ropes, bags, pottery (jabana, metad, nsra), wooden implements, skin tanning, straw weaving, and so on. Charcoal (kasal) making by cutting and burning the big wood is as old as civilization, for both domestic use and for selling. The centuries' of farming, grazing, hunting, fishing and leaching the sand, clay and soil have significant impact on the biodiversity of the basin by causing gradual land depletion not immediately noticed by the inhabitants.

\section{Effects of Grazing, Fishing and Hunting on the Biodiversity:}

Farmers agreed that use of poisons in fishing seriously affect the aquatic life, and must have been the sole reason for disappearance of some species of fishes and other water foods. They also attributed the decline in fishes to the high demand and unregulated fishing. Similarly, they argued that hunting did not contribute to the disappearance of the fauna, but the desert incursion. They argued that the wild animals and birds must be chased away in order to secure farms. Other independent studies established the fact that animal dung contain diseases, which have been affecting the communities (Leykun, 2001). The use of tractors in harrowing, and of course the animals, have long-term destructive impact on the soil, which become susceptible to torrential rains that quickly erode the soils and cause gully erosions and land-slides. However, farmers argued that tractors and cows must be used in farming as the land is sticky, tough and difficult to plough.

\section{Effects of Physical Developments}

Gigantic construction of roads impact on the soils and aquatic life, although not immediately noticed. Rapid urbanization also encourages the leaching of the streams for sand and fine stones, thus causing the drying out of streams and shortage of water for domestic use and as well affecting the aquatic life and the fauna.

Almost all informants alluded on the impact of lumbering, which they alleged goes on with the permission of the Forest Officials of the Waredas and Oromia Regional Government. Lumbering goes on day and night here, like the packing of fine sand, pebbles and big stones for road construction and for building. Like clearing of trees in the course of farming, charcoal making which involves cutting down old and matured trees significantly contribute to the disappearance of the natural vegetation and relative loss of soil fertility. The cold nature of the region influence high demand for charcoal in the towns for heating and cooking.

Informants stressed the fact that the clearing of the trees is partly influenced by the urbanization and scarcity, hike in prices and occasional shortage of natural gas and kerosene/paraffin, which influence people changed from using paraffin to fuel wood. Building in this area starts by pegging sticks. Thus, building and fuel wood professionals have emerged using trucks and horse-drawn carts supplying tons of cubic meters of logs to towns. The stubs and roots are dug out for fuel, which again disables quick regeneration of the vegetation. Fuel wood business is so lucrative that there are middlemen, using machine saws and village women and men as the fallers of wood. The desire for lumber for the rapid development of the towns has resulted into illegal lumbering and disappearance of forests and the habitat has changed. The forests harboured the fauna, which are now endangered. The sharp disappearance of trees and fauna has commensurate effect, as the dietary intake of the rural inhabitants is misbalanced, and hastening desertification and erosion. 


\section{Effects of Population increase and Urbanization}

Perhaps, beyond the purview of the farmers, land depredation can be partly attributed to rising population and increasing animal farming. The increased better livelihood and higher income in the recent years have translated into increased high fertility rate with consequent very high desire for food and fuel, and construction materials like sand, stone, mud, water and timber for bigger houses. The inherent consequence of the increasing population and higher incomes exacerbate the clearing of the forests and bushes, and the over-leaching of the streams. Indeed, the people in the catchments area are expanding their farms (ersha), increasing their animals (nsusat) and beasts of burden (ahya) for cart (gari) commuting, building large big flats (gimbbit) particularly in the emerging urban centers.

\section{Methods of Checking Erosions, and other Environmental problems}

The communities have been on individual basis attempting to check the erosion menace by terracing, piling lines of stones, hedging, making plantations of banana, coffee arabica, avocado, gista, phoenix reclinata, sugar-cane plantations, hybrid trees - Christmas tree (Tsdi and Barzau), Khat and allowing overgrowth of shrubs and local trees like thorns (grarr) and albiza gummifera. In other parts of Africa it has been known that retaining farmland trees, growing crops on ridges, and interplanting different crops densely in a single field significantly reduce soil erosion (Stock 2006).

Forests provide many social, economic, and environmental benefits. In addition to timber and paper products, forests provide wildlife habitat and recreational opportunities, prevent soil erosion and flooding, help provide clean air and water, and contain tremendous biodiversity. Forests are also an important defense against global climate change. Through the process of photosynthesis, forests produce life-giving oxygen and consume huge amounts of carbon dioxide, the atmospheric chemical most responsible for global warming. By decreasing the amount of carbon dioxide in the atmosphere, forests may reduce the effects of global warming.

It is common in urban areas to note the problems of sewage, industrial wastes, and agricultural chemicals such as fertilizers and pesticides used by the settlements around the basins polluting the ponds and streams. The U.S. Environmental Protection Agency (EPA) reports that about 37 percent of the country's lakes and estuaries, and 36 percent of its rivers, are too polluted for basic uses such as fishing or swimming during all or part of the year. In developing nations, more than 95 percent of urban sewage is discharged untreated into rivers and bays, creating a major human health hazard. Water runoff, a nonpoint source of pollution, carries fertilizing chemicals such as phosphates and nitrates from agricultural fields and yards into lakes, streams, and rivers. These combine with the phosphates and nitrates from sewage to speed the growth of algae, a type of plantlike organism. The water body may then become choked with decaying algae, which severely depletes the oxygen supply. This process, called eutrophication, can cause the death of fish and other aquatic life. Agricultural runoff may be to blame for the growth of a toxic form of algae called Pfiesteria piscicida. (Carol G. G. \& James L. G., 2007).

Indeed, the dominant biomes vegetation, such as grasslands, tropical forests, and the biotic such as the plants, animals, and bacteria found in soil and the environment are being destroyed in the course of utilizing them for building, enlarging farms and so on. Humans benefit from these smoothfunctioning ecosystems in many ways. Healthy forests, streams, and wetlands contribute to clean air and clean water by trapping fastmoving air and water, enabling impurities to settle out or be converted to harmless compounds by plants or soil. The diversity of organisms, or biodiversity, in an ecosystem provides essential foods, medicines, and other materials. But as human populations increase and their encroachment on natural habitats expands, humans are having detrimental effects on the very ecosystems on which they depend. The survival of natural ecosystems around the world is threatened by many human activities: bulldozing wetlands and clearcutting of forests, i.e. the systematic cutting of 
all trees in a specific area-to make room for new housing and agricultural land; damming rivers to harness the energy for electricity and water for irrigation; and polluting the air, soil, and water (Clement, 2006).

Since the 1960s, the Western urban centers have been concerned about the rapid environmental degradation and pollution, as they have both short immediate and long term effects on the ecosystem and human survival (Turner, 1969; Hauser, 1963). Thus, their governments, NGOs, business organizations and higher institutions have expended resources to study the problematic and proffer solutions. In order to conserve the ecosystem and curb the catastrophic depletion, many organizations and government agencies have adopted a new approach to managing natural resources. They formulated the "Ecosystem Management" that encourages practices that enable humans to obtain necessary resources using methods that protect the whole ecosystem. Ecosystem management often requires special measures to protect threatened or endangered species that play key roles in the ecosystem. This was what informed the promulgation of the Endangered Species Act (Clement, 2006). Every country now has a policy on conservation, sustainable use and protection of natural resources including plants, animals, mineral deposits, soils, clean water, clean air, and fossil fuels such as coal, petroleum, and natural gas, and Ethiopia has the Environmental Protection (MWE, 2003). They are emphatic on natural resources that are renewable - ones that may be replaced over time by natural processes, such as fish populations or natural vegetation. The goal of renewable resource conservation is to ensure that such resources are not consumed faster than they are replaced. Nonrenewable resources are those in limited supply that cannot be replaced or can be replaced only over extremely long periods of time. Nonrenewable resources include fossil fuels and mineral deposits, such as iron ore and gold ore. Conservation activities for nonrenewable resources focus on maintaining an adequate supply of these resources well into the future.

However, conservation of naturalresources conflicts with urbanization and population explosion and demand for the resources. Controversy frequently surrounds how a resource should be used, or allocated, and for whom, as the case in Nigeria. Conflicts worsen when a natural resource crosses political boundaries, when the rich buy the land and when government puts gigantic projects there without compensating the host communities (Filaba, 2004).

\section{Conclusion and Recommendation}

Both the flora and fauna are endangered around Gilgel/Gilbe rivers basins due to centuries of farming, grazing, hunting, fishing, cutting down of trees for housing and fuel, and leaching of the soil for bricks and pottery. Since the population practice mixed farming, far-away nomads come to water their flock in the river, as the gorges and streams are hardly perennial. In deed, cutting down a forest near a river, for instance, increases erosion, the wearing away of topsoil, and can lead to flooding. Eroded soil and silt cloud the river and adversely affect the whole population who use the water for domestic purposes and also affect fish and other important aquatic creatures that require clean, clear freshwater for survival.

The utilization of the environmental opportunities is done with no regard to the conservation of the ecology or observation of the existing forest and games reserve laws. Geological and paleontological studies of the basins reveal that the vegetational cover here was thick forest some centuries ago, but now reduced to Sahel and Savannah secondary vegetation as a result of centuries of human activities. This includes shifting cultivation, ironwork, hunting, fuel wood harnessing, and grazing and increased farming characterized by clearing the trees. Charcoal making is necessary for heating and cooking, as the region is relatively very cold in the morning and at night, and thus used by the villages, and as well heavily demanded in the far away urban areas. Similarly, iron smelting and smithing consume heavy charcoal which is made by cutting and burning hard wood thereby rendering the formerly forest land to grass land. The inherent concomitant of clearing of trees encourage desertification and erosion. Similarly, the people here are excellent animal farmers that every family has some cattle, horses, goats, sheep and donkeys. The animals eat low the grass and shrubs, and 
also erode banks of streams and ponds. These activities over centuries reduced the formerly guinea savannah into the now Sahel and semiarid-like land and increasing deep gorges and erosion of the banks and farms.

Therefore, protecting the biodiversity in the area of study which is the main source of our drinking water should be taken seriously. This necessarily involves combined roles of farmers, professionals, NGOs and the government. Thus, there is the need to enlighten the peasant farmers, fuel-wood and lumber dealers and brick industries on the existence of the Ethiopian Environmental Protection laws of 2003 and how to protect the endangered species. The government has been encouraging tree planting since 1971 and this should be intensified through free distribution of tree plants and tree-planting ceremonies in all villages. The government may utilize the media to enlighten the public on the need to protect the biodiversity, as it is significant to our survival.

Government of Ethiopia should insist on stringent observation of the environmental protection laws it promulgated in 2003. Also, it should include in any major contract the aspect of Environmental Impact Assessment and interface consultation with the host communities, in order for the beneficiary communities to know the impacts of such projects on their environment and what they must do to avoid damaging the biodiversity.

The universities and research-based NGOs should increase funding of researches on environmental problematics. There should be in-depth laboratory tests of the wastes generated in the towns, and of animal dung in order to know the chemical/poisonous, bacterial and worm contents of the surface waters in the basins, with the view to establishing their impact on the population. Small scale businesses and industries in the towns should be enlightened on the impact of the disposing poisonous industrial effluents particularly dead batteries, salon wastes, and other dangerous elements like cyanide, heavy metals and so on (Kolawole 2007:210; Obiri, 2007:213; Adekola 2007:221).
Many scholars have suggested on how to contend with the over-use of environmental riches (World Bank, 1995; Onyeagucha, Douglas and Ashton-Jones, 1995; Umar, 2001; Uga, 2001). The challenge of conservation is to understand the complex connections among natural resources and balance-resource-use with protection to ensure an adequate supply for future generations. Hence, a variety of resource conservation methods are used to attain this. These include reducing consumption of resources; protecting and preserving them from contamination or pollution; and reusing or recycling resources when possible. To protect natural resources from pollution necessarily include prohibiting or limiting the use of pesticides and other toxic chemicals, limiting wastewater and airborne pollutants, preventing the production of radioactive materials, and regulating drilling and transportation of petroleum products.

Some scholars found that some African conservation methods, like plantations by the banks, terracing, blockades, etc, are much more effective. Based on this, many experts argue that conservation strategies must be sensitive to regional and temporal variations and should seek to preserve and build upon local indigenous knowledge (Stock 2006).

There is therefore the need to generate data bank by environmentalist professionals on the biodiversity of the basins since at least two millenniums ago. Several other solutions to the land depletion and endangered biodiversity have been published. The problems facing the environment are vast and diverse and the destruction of the forests, fauna and surface water are some of the problems that will wreck human survival. These problems are caused by human activities. It therefore becomes necessary to safeguard the environment as it is essential to life. People must learn that Earth does not have infinite resources. Earth's limited resources must be conserved and nourished particularly in the developing countries that depend largely on agriculture. Sustainable conservation of their forests and waters will stimulate agricultural progress. 


\section{References}

Adekola F. A. et al (2007), "Removal of Cadmium form Aqueous Solution Using ManganesHexacynoferrates(II) (III)." Bulletin of the Chemical Society of Ethiopia. Vol.21 No.2 Aug. 2007 pp.221-228.CSE Addis Ababa http://www.ingentaconnect.com

Baldwin J. H., (2007) "Ecosystem." Microsoft ® Encarta ${ }^{\circledR} 2007$ Microsoft Corporation.

Clement J. P. (2006) "Environmental

Management” Microsoft ® Encarta ® 2006

Microsoft Corporation.

Filaba M. A., (2004) "A History of Karu with Specific Reference to the Consequences of the Rapid Urbanization Process of the Federal Capital City: 1976 - 2002”. Ph. D. Thesis, A.B.U. Zaria (unpublished).

Gould C. G. \& James L. Gould (2007),

"Ecosystem". Microsoft ® Encarta 2007® Microsoft Corporation.

Huang J. Y. C (2000), Air Pollution; Environment; Sewage Disposal; Water Pollution, New York

Hauser P., (1963) "The Social, Economic and Technological Problems of Rapid Urbanization". In B. F. Hoverlitz \& W. E. Moore, eds. (1963), Industrialization and society. Paris, UNESCO.

Hutchful, E. (1970) "Oil Companies and Environmental Pollution in Nigeria", in Ake, C. (ed.) Political Economy of Nigeria, Longman London:

Joel P. Clement J. P., (2005) Microsoft ® Encarta (B) 2006. Microsoft Corporation.

Jones, N.A. (1998) The ERA Handbook to the Niger Delta: The Human Ecosystems of the

Niger Delta. London: Environmental Rights Action.

Kolawole O. M. et al (2007) Studies on the Efficacy of Bridelia Ferruguinea Benth Bark

Extract for Domestic Wastewater Treatment." Bulletin of the Chemical Society of Ethiopia.

Vol.21 No.2 Aug. 2007. CSE Addis Ababa.
Leykun J. (2001) "Soil Transmitted Helminth Infections and Scistosomiasis Mansoni in Chilga District.Northwest Ethiopia." In Ethiopian Journal of Health Sciences July 2001 Vol.11 No.2. Jimma University.

Microsoft $®$ Encarta $®$ Encyclopedia, (2003)

"Solid and Liquid Waste Disposals and Pollution" (C) 1993-A2002 Microsoft Corporation.

Ministry Of Works and Environment, (2003) Environmental Protection, Addis Ababa.

Obiri S. et al (2007) "Determination of Free Cyanide and Total Cyanide Concentrations in

Surface and Underground Waters in Bogosso and Surrounding Areas In Ghana." Bulletin of

the Chemical Society of Ethiopia. Vol.21 No.2 Aug. 2007. CSE Addis Ababa.

Onyeagucha, U., O. Douglas and N. Ashton-Jones (1995) The Human Habitat of Port Harcourt. Benin City: Environmental Rights Action.

Uga, E. O. (2001) "State Creation, 'Oil Revenue' Allocation and the Political Economy of Resource Control", in Nigerian Economic Society Natural resource Use, the Environment and Sustainable Development,

Selected papers presented at 2001 annual conference, Ibadan: Nigerian Economic

Society.Umaru, I. (2001) "Our Forest Ecosystems under Threat", (March 20)

www.nigeriaworld.com, http://www.nigeriaworld.c om/feature/publication/umaru/ecosystems.html.

Stock R. (2006) "The Natural Environment of Africa."

Turner J. F. C., (1969) "Uncontrolled Urban Settlement: Problems and Policies.” G. Breese, ed. (1969), The City in Newly Developing Countries. Prentice Hall Inc, N.J. 1969, pp. 471 - 506.

World Bank (1995) Defining an Environmental Strategy for the Niger Delta.

Washington D.C.: World Bank (May).WWW:http: Environmental Impact Assessment Lectures.com/. Internet accessed 2007. 